\title{
Local Wisdom for Sustainable Education: The Sakura Traditional Art to Improve Students' Social Solidarity
}

\author{
Ulul Azmi Muhammad ${ }^{1}$, Leo Agung Sutimin², and Sudiyanto ${ }^{3}$ \\ \{sparta95@student.uns.ac.id ${ }^{1}$, leo.agung65@yahoo.co.id ${ }^{2}, \&$ \\ soeddie.fkipuns@gmail.com ${ }^{3}$ \} \\ ${ }^{1,2,3}$ Universitas Sebelas Maret, Surakarta, Indonesia
}

\begin{abstract}
Sustainability education needs to be applied to formal education in schools through integrated ways in intra-curricular activities. The purpose of this study was to investigate the Sakura's local wisdom and its potential as a learning context to improve students' social solidarity. A qualitative approach was used in this study by interviewing and reviewing books, journals, and other sources to learn about Sakura's local wisdom and its potential as a learning context. The data obtained were analyzed by descriptive exploratory analysis method. The conclusion obtained from this study is that learning by incorporating local wisdom in it can provide opportunities for students to create a meaningful understanding of the information they get. Sakura, which is local wisdom originating from the West Lampung region, has the potential to be used as a learning context in the classroom. Sakura art has an implicit meaning to establish close solidarity and intimacy among the people in the Liwa area. This makes Sakura art has a strong suspicion that it can improve students' social solidarity if applied to the context of learning. With the integration between learning and local wisdom, the sustainability of an indigenous culture can be maintained.
\end{abstract}

Keywords: Local wisdom, Sustainable education, Sakura Traditional Art, Social Solidarity

\section{INTRODUCTION}

Sustainability education, aims to help students develop knowledge, understanding, skills, values, necessary abilities and dispositions to respond to complex socio-economic problems in the 21 st century [1], [2]. The teacher has a long-term influence on this sustainable development. However, teachers often have insufficient knowledge and skills in continuing education [3]. Therefore, habituation and teaching are needed for teachers and students so that they can have knowledge and skills that are useful for sustainability [4], [5].

Education with local wisdom is education that is based more on enriching cultural values. Local wisdom itself is knowledge that is born of community experience and accumulation of 
local knowledge that can arise from thoughts, attitudes, and behavior. Learning with local wisdom teaches students to stay close to concrete situations faced by students every day. The process of integrating local wisdom in learning is a matter of innovation and novelty. Learning by incorporating local wisdom in it can provide opportunities for students to create meaningful understanding of the information they get [6].

Indonesian society is a pluralistic society with various local cultures and potentials in each region. The application of local wisdom values is needed to teach students to respect the local culture and potential in the region more. There are many ways to develop student character by exploring local wisdom and applying it as a context in learning [7]. The researchers have done many ways to elevate the values of local wisdom in learning, such as learning the local wisdom of batik jumputan to foster students' positive appreciation of the richness of the local culture [8], learning with the wisdom of Sundanese culture to develop student character [9], learning with Amatoa kajang local wisdom for environmental conservation [10], science learning with local wisdom to increase student interest [11], [12] and the local wisdom of Katoba Muna as a social and historical learning context [13].

Historical learning is very possible if you apply local wisdom-based learning. A lot of local wisdom and history of Indonesia are unknown and start to be forgotten. One of them is local wisdom originating from the West Lampung area, Sakura's performing arts name. In prehistoric times Sakura was a show used for worship ceremonies to the rulers of nature, ancestral spirits that tended to be bizarre and dressed from leaves. Sakura was first shown by the Buai Tumi community group in a place considered sacred, such as a place of worship. The purpose of Sakura show is to be able to present the spirit of the ancestors and the rulers of the universe, to get protection or assistance, and to avoid the difficulties that afflict the lives of rural people. In the present, sakura performing arts have evolved from art to worship ancestral spirits, to performing arts for entertainment and a unifying symbol, tolerance, and cooperation between communities in the Liwa area [14].

If the concept of life in tolerance, harmony, cooperation, and cultural wisdom has been understood by the community, then the solidarity of the student community will improve and it can minimize conflicts that occur both in the community and in the school environment [15]. Based on the explanation above, this study aims to investigate the Sakura local wisdom and its potential as a learning context to enhance students' social solidarity.

\section{METHOD}

A qualitative approach was used in this study by interviewing and reviewing books, journals, and other sources to learn about Sakura's local wisdom and its potential as a learning context to enhance students' social solidarity. Data collection used literature research on the Sakura local wisdom publication and documentation studies. The data obtained was analyzed by descriptive exploratory method.

This study focuses on the study of documents that describe the value and characteristics related to sakura local wisdom. The formulations of the problem in this study are what are the sakura local wisdom and how the possibility of Sakura's local wisdom as a learning context to enhance students' social solidarity.

\section{RESULTS AND DISCUSSION}

\subsection{The Sakura local wisdom}

Data on the local wisdom of Sakura's traditional arts were obtained through interviews, literature analysis, and data sourced from the archives of the West Lampung provincial 
education office. The West Lampung community believes that the worship of ancestral spirits and gods has existed since prehistoric times. Similarly, in prehistoric times Sakura was a show used for worship ceremonies to the rulers of nature, ancestral spirits that tended to be bizarre and dressed from leaves. Sakura was first shown by the Buai Tumi community group in a place considered sacred, such as a place of worship. The purpose of this Sakura show is in order to be able to present the spirit of the ancestors and the rulers of the universe, to get protection or assistance, and to avoid the difficulties that hit the lives of rural communities [16].

Buay tumi is the Lampung tribe that is the most populous in the land of Lampung. Queen Sekarmong or Queen Sekarumog is a woman who became the leader of the Buay tumi community at the end of the Hindu influence in the Sekala bekhak area. At this time, Sakura was increasingly popular among the Liwa people, so this art was not only showed during the harvest period, but also when the full moon in the square. After this period, the turmoil of power struggles began to occur. The power of Queen Sekarmong and its people collapsed by four people from the kingdom of Pagar Ruyung, namely, Buung Belung, Buer Nyerupa, Buay Pernong and Buay Bejalan Diwey, as the messenger of Islam in Liwa. These four families can subdue the queen of Sekarmong and succeed in mastering the Sekala area and their people hold Islam until now [17].

At the present time Sakura art is a masquerade party held every Eid by the people of West Lampung, especially in the Sekala bekhak area. The word "Sakura" comes from the word "Sakukha" which means a face cover. The change of the word "sakukha" becomes "sakura" because it follows the development of Indonesian grammar in general, so that the local Lampung community and immigrants can easily pronounce it [16].

Sakura's art has certain elements that become the characteristics of its identity. These characteristics can be known from tarub or stronghold, the attraction of pencak silat, food and drinks, Sakura visits, nyakak buah by Sakura Kamak, accompaniment music, clothing, Sakura's motion style, and Sakura types [17]. Before the nyakak buah or Pinang climbing event began, Sakura participants paraded around the Pinang climbing arena. The parade was carried out mainly by Sakura Kamak. The process of the show is called a parade party that goes around the Sakura party arena. This parade took place spontaneously led by one of the adat leaders who determined the route to be taken. The pattern or behavior of the Sakura participants was very attractive to the audience, so the people around the arena flocked to join Sakura. The audience can immediately see the strangeness and uniqueness of Sakura's fashion and behavior in her appearance [18]. The holding of the Sakura art consists of several stages of the event as a series of traditional people's party processes. The stages of the Sakura process are summarized in Table 1.

Table.1 Stages of the sakura art process

\begin{tabular}{lll}
\hline No & Sakura art stages & Explanation \\
\hline 1 & Preparation stage & $\begin{array}{l}\text { During the preparation stage a discussion was held between the } \\
\text { traditional leaders and village community leaders to discuss the plan } \\
\text { for holding the Sakura art party. Deliberation is carried out to produce } \\
\text { a collective agreement which covers the following matters: a) time of } \\
\end{array}$ \\
& $\begin{array}{l}\text { implementation; b) financing; c) facilities and equipment; d) } \\
\text { participants who will be invited; and e) Sakura party arrangements }\end{array}$ \\
& $\begin{array}{l}\text { At this stage it is marked by the sound of loud music. The opening } \\
\text { music is played by local village traditional arts groups. At this time all } \\
\text { participants were present. Generally Sakura players have not completed } \\
\text { and wear their costumes, they are only worn when they are near the } \\
\text { arena }\end{array}$ \\
&
\end{tabular}




\begin{tabular}{lll}
\hline No & Sakura art stages & Explanation \\
\hline 3 & $\begin{array}{l}\text { The main stage of } \\
\text { Sakura's party }\end{array}$ & $\begin{array}{l}\text { The main stage of Sakura's art is the Sakura parade and Nyakak buah. } \\
\text { The traced route is a village walk around the party arena. Nyakak buah } \\
\text { is a competition for sakura participants to climb Pinang trees that have } \\
\text { been oiled. Participants compete to reach the top of the pinang tree to } \\
\text { get a prize } \\
\text { At this stage it is generally filled with prayers with the Sakura art party } \\
\text { participants and ends with closing music }\end{array}$ \\
\hline
\end{tabular}

Sakura Nyakak Buah has a very deep meaning among the Liwa community, especially in the villages of Kenali, Canggu, Kegeringan, and Kuta Besi. Sakura is a symbol of prosperity through abundant harvests, so that the harmony of the Liwa community is formed. Like Kamak Sakura which is used for parades around the village and this is believed to be a waste of misfortune and calamity in the lives of rural people. The community is very happy with Sakura art as an entertainment to welcome the Eid al-Fitr. The meaning implied in Sakura's show is to establish close relations of solidarity among the people in the Liwa area. [17].

\subsection{Learning with local wisdom}

The value of local wisdom comes from people's thinking which has long been believed to be good knowledge. People's thoughts and behavior based on local wisdom values are considered to be able to create happiness and a peaceful life for everyone in the community. In a thought, local wisdom will create valuable values and norms for the benefit of shared life and social solidarity. In the implementation process, local wisdom will lead to the application of these values and norms in the form of effective behavior of people, rather than transferring values or norms for personal gain. [15].

Through learning with local wisdom students obtain the values, attitudes, skills, and knowledge of learning not only from school but also from family and the environment. The value of local wisdom integrated in learning serves to prepare students to be ready to penetrate the millennial era that utilizes advanced technology [19]. Learning with local wisdom has been carried out by researchers from various regions of Indonesia. A summary of the results of the literature review on local wisdom based on the field of study is presented in Table 2 .

Table 2 Learning that has used local wisdom

\begin{tabular}{|c|c|c|c|}
\hline No & Field of study & Local wisdom & Researchers \\
\hline \multirow[t]{2}{*}{1} & Biology & Ngata Toro community in utilizing forest resources & [7] \\
\hline & & Timor local Wisdom & [20] \\
\hline \multirow[t]{2}{*}{2} & Physics & Kampung Naga, dan the local wisdom in West Java & [21] \\
\hline & & Developing character based on local wisdom in Bali & [22] \\
\hline 3 & Mathematics & $\begin{array}{l}\text { The local wisdom content that used are fish, coconut, } \\
\text { fishing activities, tsunami }\end{array}$ & [23] \\
\hline 4 & Religion & Thanksgiving and ketupat local wisdom & [24], \\
\hline 5 & Lenguange & Batak Toba language local wisdom & [25] \\
\hline 6 & History & Socio-cultural value & [15] \\
\hline
\end{tabular}

Based on table 2, many researchers have integrated several subjects with local wisdom. Local wisdom appointed by researchers also comes from many regions in Indonesia. Learning that integrates local wisdom in it can be done in various ways, such as making local wisdom as the context in the module [26], text-book [27], even flash applications media and electronic books [23] or local wisdom as a learning model [28]. The integration between learning in the classroom and local wisdom has been proven by researchers to improve various things, 
including science process skills and scientific attitudes [29], positive character improvement [22], student interst [11], and social solidarity [15].

In the current conditions, the culture continues to diminish due to changes in the social order towards a generation that does not support the sustainability of local wisdom, and advances in science and technology that are often treated unwise so as to leave local wisdom behind. Therefore it is necessary to explore local wisdom in schools [30]. The revised 2013 curriculum encourages teachers to use context in school subjects that lead to Education for Sustainability. [30].

Based on the description above, doing learning with the context of local wisdom Sakura traditional arts in Lampung is something that can be done. In addition to the continuity of traditional arts, it is also thought to be able to increase awareness of students' social solidarity. To succeed in sustainable learning with local wisdom, the teacher needs to 1) learn the local wisdom and seek information from the community both observing and interviewing local residents, 2) learning about folklore, asking philosophers and village scholars, 3) looking for more knowledge and learning various ways of visiting other schools to learn, 4) In the learning process one subject in particular. Teachers must attract the potential of local wisdom to participate as guest speakers or consultants in the classroom, and 5) Teachers must provide a variety of teaching and learning processes that are not fixated with school tesx books [31].

\section{CONCLUSION}

Learning by incorporating local wisdom in it can provide opportunities for students to create meaningful understanding of the information they get. Sakura, which is local wisdom originating from the West Lampung region, has the potential to be used as a learning context in the classroom. Sakura art has an implicit meaning to establish close solidarity and intimacy among the people in the Liwa area. This makes Sakura art has a strong suspicion that it can improve students' social solidarity if applied to the context of learning. With the integration between learning and local wisdom, the sustainability of an indigenous culture can be maintained

\section{REFERENCES}

[1] Evans N S Stevenson R B Lasen M Ferreira J A and Davis J, 2017 Approaches to embedding sustainability in teacher education: A synthesis of the literature Teach. Teach. Educ. 63 p. 405-417.

[2] Shidiq A S and Yamtinah S, 2019 Pre-service chemistry teachers ' attitudes and attributes toward the twenty-first century skills J. Phys. Conf. Ser. 1157, 042014 p. 1-8.

[3] Aksela M, 2016, Education for Sustainable Development in Chemistry Teacher Education.

[4] Burmeister M Rauch F and Eilks I, 2012 Education for Sustainable Development (ESD) and chemistry education Chem. Educ. Res. Pract. 13, 2 p. 59-68.

[5] Juntunen M K and Aksela M K, 2014 Education for sustainable development in chemistrychallenges, possibilities and pedagogical models in Finland and elsewhere Chem. Educ. Res. Pract. 15, 4 p. 488-500.

[6] Hartini S Firdausi S Misbah and Sulaeman N F, 2018 The Development of Physics Teaching Materials Based on Local Wisdom to Train Saraba Kawa Characters J. Pendidik. IPA Indones. 7, 2 p. 130-137.

[7] Yuliana Sriyati S and Sanjaya Y, 2017 Local Wisdom of Ngata Toro Community in Utilizing Forest Resources as a Learning Source of Biology AIP Conf. Proc. 1868, 100007.

[8] Atmojo S E, 2015 Learning Which Oriented on Local Wisdom to Grow A Positive 
Appreciation of Batik Jumputan (Ikat Celup Method) J. Pendidik. IPA Indones. 4, 1 p. $48-$ 55.

[9] Permatasari I and Hakam K A, 2018 The Development of Character Education Based on Sundanese Local Wisdom IOP Conf. Ser. Earth Environ. Sci. 145, 012124 p. 1-5.

[10] Surtikanti H K Syulasmi A and Ramdhani N, 2017 Traditional Knowledge of Local Wisdom of Ammatoa Kajang Tribe ( South Sulawesi ) about Environmental Conservation J. Phys. Conf. Ser. 895, 012122.

[11] Shidiq A S, 2016 Pembelajaran Sains Kimia Berbasis Etnosains Untuk Meningkatkan Minat Dan Prestasi Belajar Siswa in Seminar Nasional Kimia dan Pendidikan Kimia VIII p. 227-236.

[12] Yamtinah S Masykuri M Ashadi M and Shidiq A, 2017 An Analysis of Students' Science Process Skills in Hydrolysis Subject Matter Using Testlet Instrument in Proceedings of the International Conference on Teacher Training and Education 2017 (ICTTE 2017) 158, Ictte p. 101-110.

[13] Bauto L M, 2013 Socio-Cultural Values as Community Local Wisdom Katoba Muna in The Development of Learning Materials Int. J. Hist. Educ. 18, 2 p. 195-218.

[14] Koentjaraningrat, 1980 Pengantar Ilmu Antropologi Jakarta: Aksara Baru.

[15] Mujiyati N Warto and Sutimin L A, 2017 The Strategies to Improve Social Solidarity of Senior High School Students through Am. Int. J. Soc. Sci. 6, 1 p. 65-70.

[16] Fauzan, 2016 Makna Simbolik Topeng Sakura Pada Masyarakat Adat Lampung J. Stud. Agama dan Pemikir. Islam 10, 1 p. 223-256.

[17] Mustika I W, 2011, Perkembangan Bentuk Pertunjukan Sakura dalam Konteks Kehidupan Masyarakat Lampung Barat Tahun 1986-2009, Universitas Gadjah Mada.

[18] Laksito Oki Drajat E D and Bambang, 1992, Topeng Lampung: Tinjauan Awal Dramatari Tupping dan Pesta Sakura, Lampung Barat.

[19] Yufiarti Rivai R K and Pratiwi A P, 2018 Development of Adiwiyata Curriculum Model Based on Local Wisdom AIP Conf. Proc. 2019, 030012.

[20] Ardan A S, 2016 The Development of Biology Teaching Material Based on the Local Wisdom of Timorese to Improve Students Knowledge and Attitude of Environment In Caring the Persevation of Environment Int. J. High. Educ. 5, 3 p. 190-200.

[21] Nasrudin D Rochman C and Muhyiddin A, 2018 Physics Phenomena on Housing Architecture in Kampung Naga IOP Conf. Ser. Mater. Sci. Eng. 288, 012044.

[22] Suastra I W Jatmiko B Ristiati N P and Yasmini L P B, 2017 Developing Characters Based on Local Wisdom Of Bali In Teaching Physics In Senior High School J. Pendidik. IPA Indones. 6, 2 p. 306-312.

[23] Abadi M K Asih E C M and Jupri A, 2018 Development of Interactive Mathematics Learning Material Based on Local Wisdom with .swf Format J. Phys. Conf. Ser. 1013, 012131.

[24] Bolotivo R, 2018 Thanksgiving and Ketupat: Local Wisdom Dimensions and Ride of Religious Harmony in North Sulawesi IOP Conf. Ser. Earth Environ. Sci. 175, 012134.

[25] Sibarani R, 2017 Batak Toba society's local wisdom of mutual cooperation in Toba Lake area: a linguistic anthropology study Int. J. Hum. Rights Healthc.

[26] Putry A A Warsono Supahar and Jumadi, 2018 Students and Teachers 'Necessity toward Multimedia Learning Modules ( MLMs ) Based on Benthik Local Wisdom to Provide Students ' Physics Initial Knowledge J. Phys. Conf. Ser. 1097, 012014.

[27] Ardan A S Ardi M Hala Y Supu A and Dirawan G D, 2015 Needs Assessment to Development of Biology Textbook for High School Class X-Based the Local Wisdom of Timor Int. Educ. Stud. 8, 4 p. 52-59. 
[28] Yoda I K, 2017 The Development of Cooperative Learning Model Based on Local Wisdom of Bali for Physical Education, Sport and Health Subject in Junior High The Development of Cooperative Learning Model Based on Local Wisdom of Bali for Physical Education, Sport and Hea IOP Conf. Ser. Earth Environ. Sci. 180, 012166.

[29] Dwianto A Wilujeng I Prasetyo Z K and Suryadarma I G P, 2017 The Development of Science Domain Based Learning Tool Which Is Integrated With Local Wisdom to Improve Science Process Skill And Scientific Attitude J. Pendidik. IPA Indones. 6, 1 p. 23-31.

[30] Hartadiyati E Rizqiyah K Wiyanto Rusilowati A and Prasetia A P B, 2017 The Integrated Model of Sustainability Perspective in Spermatophyta Learning Based on Local Wisdom J. Phys. Conf. Ser. 895, 012051.

[31] Pornpimon C Wallapha A and Prayuth C, 2014 Strategy Challenges the Local Wisdom Applications Sustainability in Schools Procedia - Soc. Behav. Sci. 112, Iceepsy 2013 p. 626-634. 